Article

\title{
Anthocyanins Isolated from Vitis coignetiae Pulliat Enhances Cisplatin Sensitivity in MCF-7 Human Breast Cancer Cells through Inhibition of Akt and NF-KB Activation
}

\author{
Anjugam Paramanantham ${ }^{1,2,+}$, Min Jeong Kim ${ }^{1,+}$, Eun Joo Jung ${ }^{3}$, Hye Jung Kim ${ }^{4}$, \\ Seong-Hwan Chang ${ }^{5}$, Jin-Myung Jung ${ }^{6}$, Soon Chan Hong ${ }^{7}$, Sung Chul Shin ${ }^{8}$, \\ Gon Sup Kim ${ }^{2, *(1)}$ and Won Sup Lee ${ }^{1, *(D)}$
}

1 Departments of Internal Medicine, Institute of Health Sciences, Gyeongsang National University Hospital, Gyeongsang National University School of Medicine, Jinju 660-702, Korea; anju.udhay@gmail.com (A.P.); bokdae@hanmail.net (M.J.K.)

2 Research Institute of Life Science and College of Veterinary Medicine, Gyeongsang National University, 501 Jinju-daero, Jinju 52828, Korea

3 Departments of Biochemistry Institute of Health Sciences, Gyeongsang National University Hospital, Gyeongsang National University School of Medicine, Jinju 660-702, Korea; eunjoojung@gnu.ac.kr

4 Department of Pharmacology, College of Medicine, Institute of Health Sciences Gyeongsang National University School of Medicine, Jinju 660-702, Korea; hyejungkim@gnu.ac.kr

5 Department of Surgery, Konkuk University School of Medicine, Seoul 05030, Korea; csh@kuh.ac.kr

6 Departments of Neurosurgery, Institute of Health Sciences and Gyeongsang National University Hospital, Gyeongsang National University College of Medicine, 90 Chilam-dong, Jinju 660-702, Korea; gnuhjjm@gnu.ac.kr

7 Departments of Surgery, Institute of Health Sciences and Gyeongsang National University Hospital, Gyeongsang National University College of Medicine, 90 Chilam-dong, Jinju 660-702, Korea; hongsc@gnu.ac.kr

8 Department of Chemistry, Research Institute of Life Science, Gyeongsang National University, Jinju 660-701, Korea; scshin@gsnu.ac.kr

* Correspondence: 1wshmo@hanmail.net or lwshmo@gnu.ac.kr (W.S.L.); gonskim@gnu.ac.kr (G.S.K.); Tel.: +82-55-750-8733 (W.S.L.); +82-55-772-2356 (G.S.K.); Fax: +82-55-758-9122 (W.S.L.)

+ These authors contributed equally to this work.

Academic Editor: Luciana Mosca

Received: 16 July 2020; Accepted: 7 August 2020; Published: 9 August 2020

Abstract: Anthocyanins isolated from Vitis coignetiae Pulliat (Meoru in Korea) (AIMs) have various anti-cancer properties by inhibiting Akt and NF- $\mathrm{KB}$ which are involved in drug resistance. Cisplatin (CDDP) is one of the popular anti-cancer agents. Studies reported that MCF-7 human breast cancer cells have high resistance to CDDP compared to other breast cancer cell lines. In this study, we confirmed CDDP resistance of MCF-7 cells and tested whether AIMs can overcome CDDP resistance of MCF-7 cells. Cell viability assay revealed that MCF-7 cells were more resistant to CDDP treatment than MDA-MB-231 breast cancer cells exhibiting aggressive and high cancer stem cell phenotype. AIMs significantly augmented the efficacy of CDDP with synergistic effects on MCF-7 cells. Molecularly, Western blot analysis revealed that CDDP strongly increased Akt and moderately reduced p-NF- $\kappa B$ and $\mathrm{p}-\mathrm{I} \kappa \mathrm{B}$ and that AIMs inhibited CDDP-induced Akt activation, and augmented CDDP-induced reduction of p-NF- $\mathrm{kB}$ and $\mathrm{p}-\mathrm{I} \kappa \mathrm{B}$ in MCF-7 cells. In addition, AIMs significantly downregulated an anti-apoptotic protein, XIAP, and augmented PARP-1 cleavage in CDDP-treated MCF-7 cells. Moreover, under TNF- $\alpha$ treatment, AIMs augmented CDDP efficacy with inhibition of NF- $\mathrm{KB}$ activation on MCF-7 cells. In conclusion, AIMs enhanced CDDP sensitivity by inhibiting Akt and NF-kB activity of MCF-7 cells that show relative intrinsic CDDP resistance. 
Keywords: synergistic effects; CDDP; meoru; phytochemicals; AIMs; cisplatin resistance

\section{Introduction}

Breast cancer is one of the most frequently occurring cancers and 1 in 4 diagnosed cancer cases for women had breast cancer in 2018 [1]. Recent studies have shown that the rate of cancer incidence has declined. However, breast cancer continues to be the reason for the high fatality rate in females, especially between the ages of 34-65 in many countries including South Korea [2]. The main reason for high fatality is the treatment failure due to drug resistance [3]. Many researchers believe one possible way to overcome or delay the development of resistance is the combined administration of drugs with non-overlapping mechanisms of action, which is a combination chemotherapy. However, this combination approach with multiple chemotherapeutic agents leads to serious toxicities even to death. Hence, recent solutions to drug resistance are generally based on the addition of novel targeted drugs or non-toxic drugs that increase efficacy or previous drug sensitivity by identification of cancer cell dependencies and/or the resistance mechanisms [4].

Cisplatin (cis-diaminedichloroplatinum, CDDP) has been one of the most widely used effective chemotherapeutic agents for more than 30 years. CDDP is a DNA damaging drug that induces inhibition of DNA synthesis and/or RNA transcription, and also cell cycle arrest [4-6]. CDDP resistance is associated with various mechanisms such as deregulated MAPK or PI3K/Akt pathway [7], increased tolerance of DNA damage [8], anti-apoptotic proteins [9], or suppressed apoptotic activities [10].

Phytochemicals showed anti-cancer effects by safely modulating tumor suppressor genes or the signaling related to cancer cell survival or death [11]. Many interests have been drawn in cancer prevention and treatment. However, there are only some trials to overcome drug resistance or to increase chemotherapy efficacy by these phytochemicals. We here consider how phytochemicals can be integrated to prevent, delay, or revert resistance to chemotherapy. Hence, as an initial step, we tested whether phytochemicals increased chemotherapy efficacies by inhibiting a well-known signaling mechanism involved in CDDP resistance events through various mechanisms were reported for CDDP resistance.

Recently, many studies reported that the anthocyanins have anti-cancer, anti-inflammatory, and angiogenesis activity [12-14]. We reported that anthocyanins isolated from Vitis coignetiae Pulliat (Meoru in Korea) (AIMs) have various anti-cancer properties and promotes apoptosis by inhibiting Akt and NF- $k B[15,16]$. Activation of Akt and NF- $k B$ is one of the CDDP resistance mechanisms [17]. In addition, there are many studies to overcome the drug resistance by targeting NF- $k B$ or Akt $[18,19]$. Breast cancer is one of the most common causes of cancer mortality in women [20]. Literature studies reported that MCF-7 human breast cancer cells have high resistance to CDDP compared to other breast cancer cell lines; the IC50 value of MCF-7 cells to CDDP was found to be $97 \mu \mathrm{M}$, whereas that of MDA-MB-231 breast cancer cells that show aggressive and high cancer stem cell phenotypes were $36 \mu \mathrm{M}$ [21]. In addition, MCF-7 cells also have a defect in inducing caspase-mediated apoptosis because of defect in caspase 3 expression [22]. In this study, we postulated that the AIMs can enhance the effect of CDDP by the inhibition of NF- $\mathrm{kB}$ and Akt signaling on MCF-7 cells that showed intrinsic CDDP resistance. Hence, we investigated the anti-cancer effects of AIMs on CDDP-treated MCF-7 cells that show relative intrinsic CDDP resistance, and their underlying cellular mechanisms. 


\section{Results}

2.1. MCF-7 Cells Were More Resistant to CDDP Than MDA-MB-231 Cells, and Anthocyanins Isolated from Vitis coignetiae Pulliat (AIMs) Induced Anti-Proliferative Effects

To evaluate the effect of CDDP on human breast cancer cell lines, we treated different concentrations of $\operatorname{CDDP}(0,2.5,5,10$, and, $20 \mu \mathrm{g} / \mathrm{mL})$ in both MCF-7 and MDA-MB-231 cells for $48 \mathrm{~h}$. Trypan blue exclusion assay revealed that CDDP had far less effects on MCF-7 cells than on MDA-MB-231 cells. The morphological analysis also divulged that cell proliferation of MDA-MB-231 cells was greatly inhibited compared to that of MCF-7 cells in treatment with CDDP (Figure 1A). These results suggest that MCF-7 cells are resistant to CDDP treatment. Trypan blue assay clearly revealed that AIMs inhibit cell viability in a dose-dependent manner in MCF-7 cells. MCF-7 cells treated with AIMs at the concentration of $400 \mu \mathrm{g} / \mathrm{mL}$ showed $46 \%$ and $42 \%$ cell viability at $48 \mathrm{~h}$ and $72 \mathrm{~h}$, respectively (Figure 1C). Furthermore, a microscopic observation also showed suppression of cell proliferation and some cell death (Figure 1D). These results indicate that AIMs alone mainly produced anti-proliferative effects on MCF-7 cells.

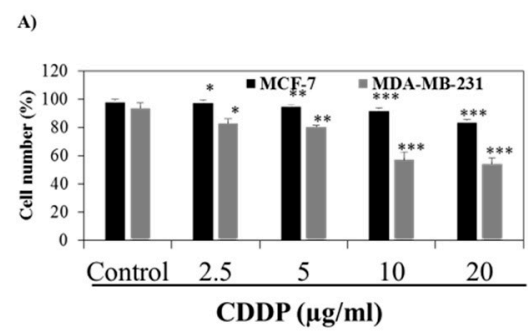

C)

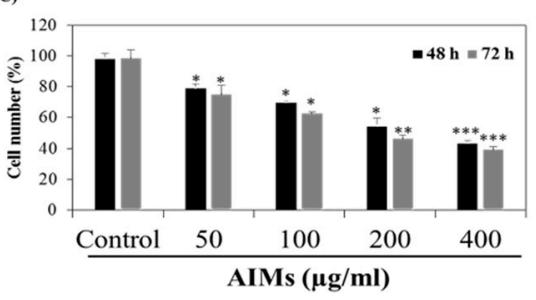

B)

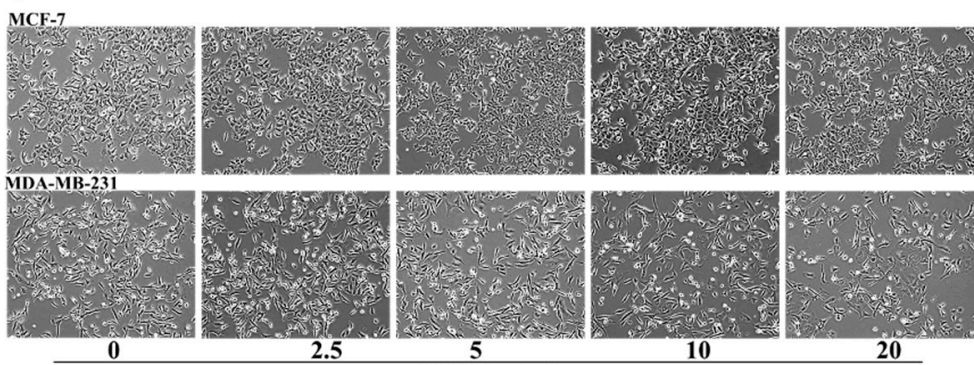

$\operatorname{CDDP}(\mu \mathrm{g} / \mathrm{ml})$

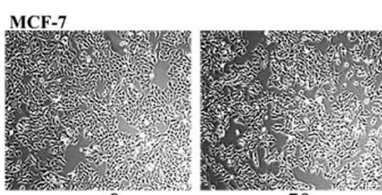

50

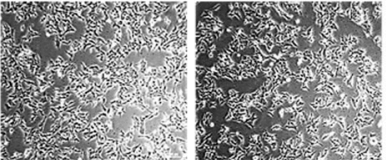

200

AIMs $(\mu \mathrm{g} / \mathrm{ml})$

Figure 1. The inhibitory effects of CDDP and AIMs on breast cancer cell lines. (A) trypan blue exclusion assay to analyze the CDDP sensitivity of MCF-7 and MDA-MB-231 cells. Cells were treated with a concentration of $0,2.5,5,10$, and $20 \mu \mathrm{g} / \mathrm{mL}$ of CDDP, and trypan blue assay was performed $48 \mathrm{~h}$ after CDDP treatment. MCF-7 cells showed relative resistance to CDDP and MDA-MB-231 cells showed inhibition of cell proliferation in a dose dependent manner; (B) morphological representation of MCF-7 and MDA-MB-231 cells under a light microscope. Cells were treated with CDDP at different concentrations $(0,2.5,5,10$, and $20 \mu \mathrm{g} / \mathrm{mL})$ for $48 \mathrm{~h}$; (C) trypan blue exclusion assay for AIMs sensitivity of MCF-7 cells. Cells were treated with an indicated of AIMs for 48 and 72 h; (D) morphological representation of MCF-7 cells under the light microscope. Cells were treated with AIMs at different concentrations $(0,50,100,200$, and $400 \mu \mathrm{g} / \mathrm{mL})$ for 48 and $72 \mathrm{~h}$ showed inhibitory effects in a dose dependent manner. All data shown are the mean \pm SD of three different experiments performed independently. ${ }^{*} p<0.05,{ }^{* *} p<0.01$ and ${ }^{* * *} p<0.0001$ between untreated control and treated groups.

\subsection{AIMs Induced a Synergistic Effect on Cell Death of MCF-7 Cells with Co-Treatment of CDDP}

MCF-7 cells are relatively resistant to CDDP as compared to other breast cancer cell lines (Figure 1A) [23]. MCF-7 cells that were treated with AIMs combined with CDDP showed a high number of cell death at $48 \mathrm{~h}$. Morphological analysis through a phase contrast microscope also revealed an increase in cell death and deformed cells with the combined treatment of AIMs and CDDP. To evaluate the type of cell death with DAPI staining, MCF-7 cells clearly displayed condensed and 
fragmented nuclei, the hallmark cell morphology of apoptosis (Figure 2A). In addition, the MTT assay revealed that there is a synergetic effect between CDDP and AIMs on cell viability of MCF-7 cells. The synergistic effect is calculated as described previously [24]; the viability of cells treated with CDDP alone, AIMs alone, and a combination of CDDP and AIMs group were $81 \%, 58 \%$, and 37\%, respectively (Figure 2B). These results strongly suggest that AIMs may aid MCF-7 cells to overcome CDDP resistance.

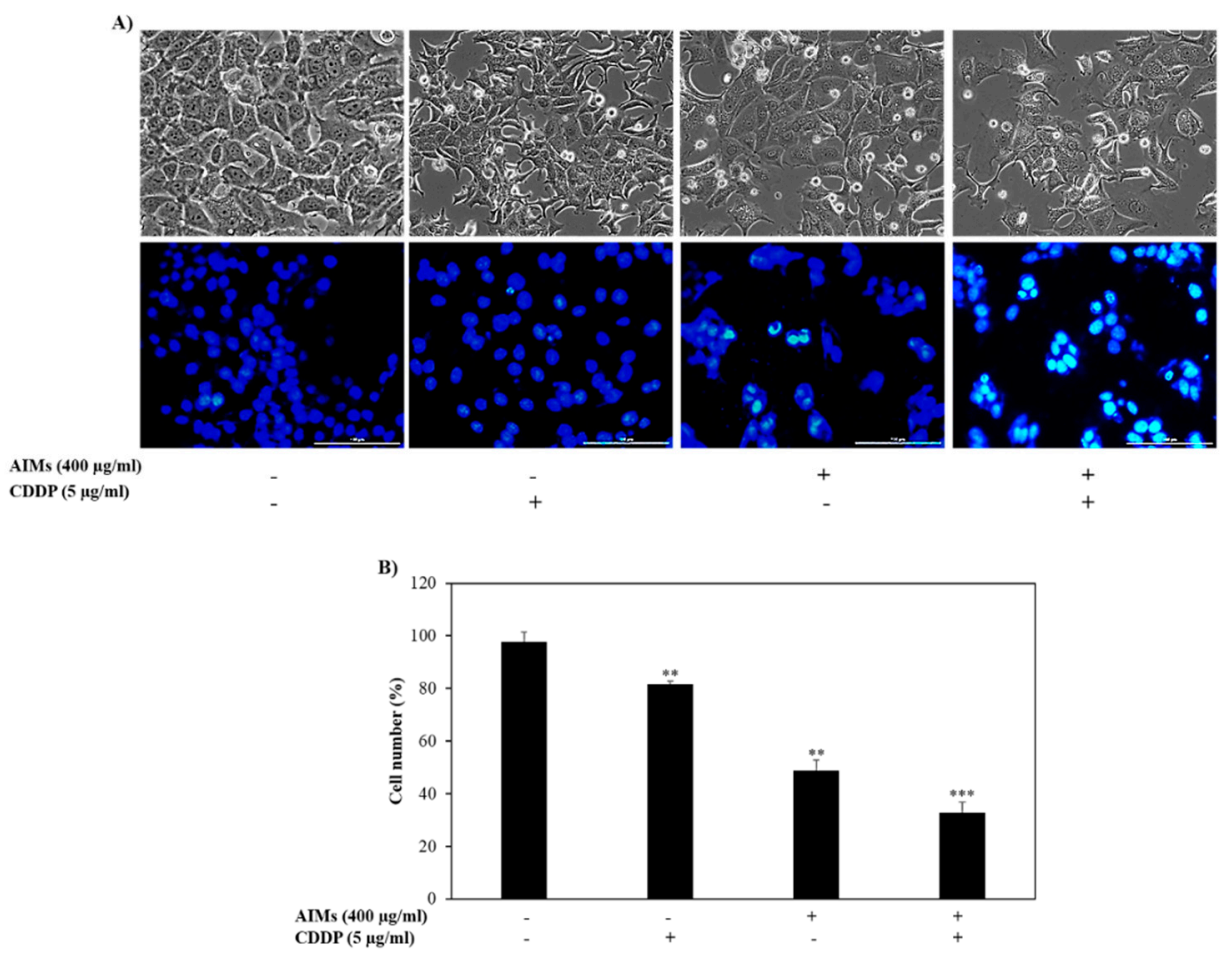

Figure 2. The inhibitory effects of anthocyanins isolated from Vitis coignetiae Pulliat (anthocyanins isolated from meoru, AIMs) and/or cis-diaminedichloroplatinum (CDDP) on MCF-7 cells human breast cancer cells. The cells were treated with $400 \mu \mathrm{g} / \mathrm{mL}$ of AIMs one hour before $5 \mu \mathrm{g} / \mathrm{mL}$ of CDDP treatment and incubated for $48 \mathrm{~h}$. (A) After $48 \mathrm{~h}$ of treatment, pictures were taken representing cellular and nuclear morphology of the cells which showed damages cells and decreased cell proliferation. DAPI staining was used to show the deformed nucleus. (B) The inhibitory effects of combined AIMs and CDDP were analyzed through the trypan blue exclusion assay. "+" and "-" represents the presence and absence of the compound, absence of the compound specified. The data shown are mean \pm SD of three different experiments performed separately. ${ }^{* *} p<0.05$ versus treated group and ${ }^{* * *} p<0.05$ versus CDDP treated group.

\subsection{AIMs Enhanced CDDP Efficacy in MCF-7 Cells That Showed Relative CDDP Resistance}

To explore whether AIMs co-treated with CDDP augments CDDP-induced cell cycle arrest or cell death of MCF-7 cells, we evaluate the distribution of cell cycle by flow cytometer. PI staining depicts that a combination treatment with AIMs and CDDP showed a significant increase in the cell populations in the sub-G1 phase. These results indicated that there was a synergistic effect between AIMs and CDDP on MCF-7 cells; the percentage of cells in the sub-G1 phase of control, CDDP alone, AIMs alone, and combination of CDDP and AIMs group were 6.3\%, 7.4\%, 17.4\%, and 31.5\%, respectively (Figure 3A). Furthermore, Annexin V/PI staining also showed an increasing number of dead cells when AIMs and CDDP were treated together. The number of dead cells in the 4th quadrant drastically increased from $1.6 \%$ to $35.4 \%$ when AIMs were treated $1 \mathrm{~h}$ before CDDP treatment (Figure 3B). Taken together, these results signify that AIMs enhanced CDDP efficacy in MCF-7 cells that showed relative CDDP resistance. 

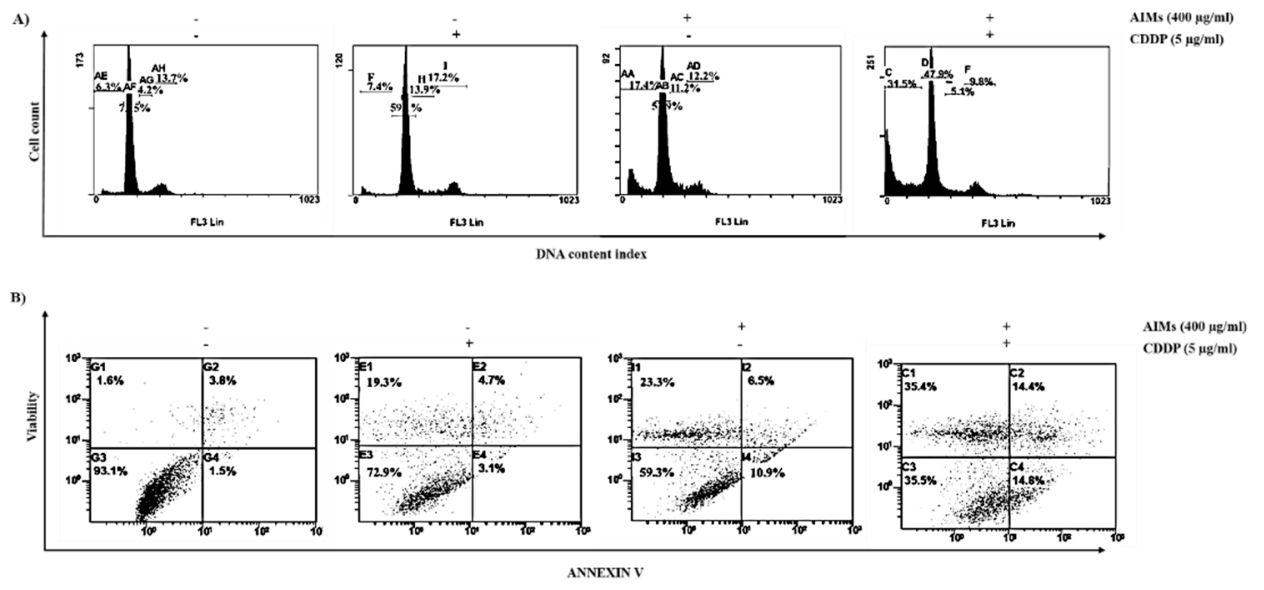

Figure 3. Synergistic effects between AIMs and CDDP on cell death of MCF-7 cells. MCF-7 cells were treated with $400 \mu \mathrm{g} / \mathrm{mL}$ of AIMs $1 \mathrm{~h}$ before $5 \mu \mathrm{g} / \mathrm{mL}$ of CDDP treatment and incubated for $48 \mathrm{~h}$ (A) Flow cytometry for cell cycle analysis. MCF-7 cells were stained with PI (Propidium Iodide) and subjected to flow cytometry analysis. The population of the cells in subG1 phase has been highly increased when AIMs and CDDP were treated together (B) flow cytometry with Annexin V/PI double staining. MCF-7 cells were treated with the given treatment $(400 \mu \mathrm{g} / \mathrm{mL}$ of AIMs and $5 \mu \mathrm{g} / \mathrm{mL}$ of CDDP for $48 \mathrm{~h}$ ) and stained with Annexin V/PI to analyze through flow cytometry. The number of cells in the fourth quadrant increased significantly showing high cell death when AIMs and CDDP treated together. "+" and "-"represents the presence and absence of the compound, absence of the compound specified.

\subsection{AIMs Enhanced CDDP Efficacy by Inhibiting NF- $\kappa B$ and Akt Activation in MCF-7 Cells That Showed Relative CDDP Resistance}

MCF-7 cells acquire CDDP resistance through activating numerous pathways which include protein kinase activation such as Akt and PKC (protein kinase C) [21]. It is reported that CDDP induced a more marked decrease in $\mathrm{p}-\mathrm{I} \kappa \mathrm{B}$ and NF- $\mathrm{KB}$ activity in CDDP-sensitive cells than in CDDP-resistant cells [25]. Western blot analysis revealed that CDDP, consistent with the previous finding, strongly increased Akt and moderately reduced p-NF- $k B$ and p-I $\kappa B$ (Figure $4 \mathrm{~A}$ ) and that AIMs inhibited CDDP-induced Akt activation, and augmented CDDP-induced reduction of $\mathrm{p}-\mathrm{NF}-\mathrm{kB}$ and p-IкB in MCF-7 cells. In addition, AIMs significantly downregulated an anti-apoptotic protein, XIAP and augmented PARP-1 cleavage when treated with CDDP (Figure 4). These results suggest that AIMs, when treated with CDDP, could promote cell death of MCF-7 cells by inhibition of Akt phosphorylation and NF- $\mathrm{kB}$ activation followed by inhibition of XIAP.

2.5. TNF- $\alpha$ Enhanced the CDDP Sensitivity of Both MCF-7 and MDA-MB-231 Cells, But the Intensity Was Different between Them; MCF-7 Cells Are Still Less Sensitive to the Combination Treatment of TNF- $\alpha$ and $C D D P$

It was reported that TNF- $\alpha$ increased CDDP sensitivity of cancer cells [26]. We tested whether TNF- $\alpha$ augmented CDDP sensitivity of both MCF-7 and MDA-MB-231 cells because it was reported that the two cells showed different sensitivity to TNF- $\alpha$ [27]; MCF-7 cells were responsive to TNF- $\alpha$ treatment while MDA-MB-231 cells are resistant to it. As shown in Figure 5, TNF- $\alpha$ increased CDDP sensitivity of both the cancer cells, but there was a difference in intensity; an additive effect and synergistic effect were observed between CDDP and TNF- $\alpha$ in MCF-7 cells and MDA-MB-231 cells, respectively. This finding suggests that MCF-7 cells were still less sensitive to CDDP and TNF- $\alpha$ treatment even though MCF-7 cells did not show resistance to TNF- $\alpha$ alone. 

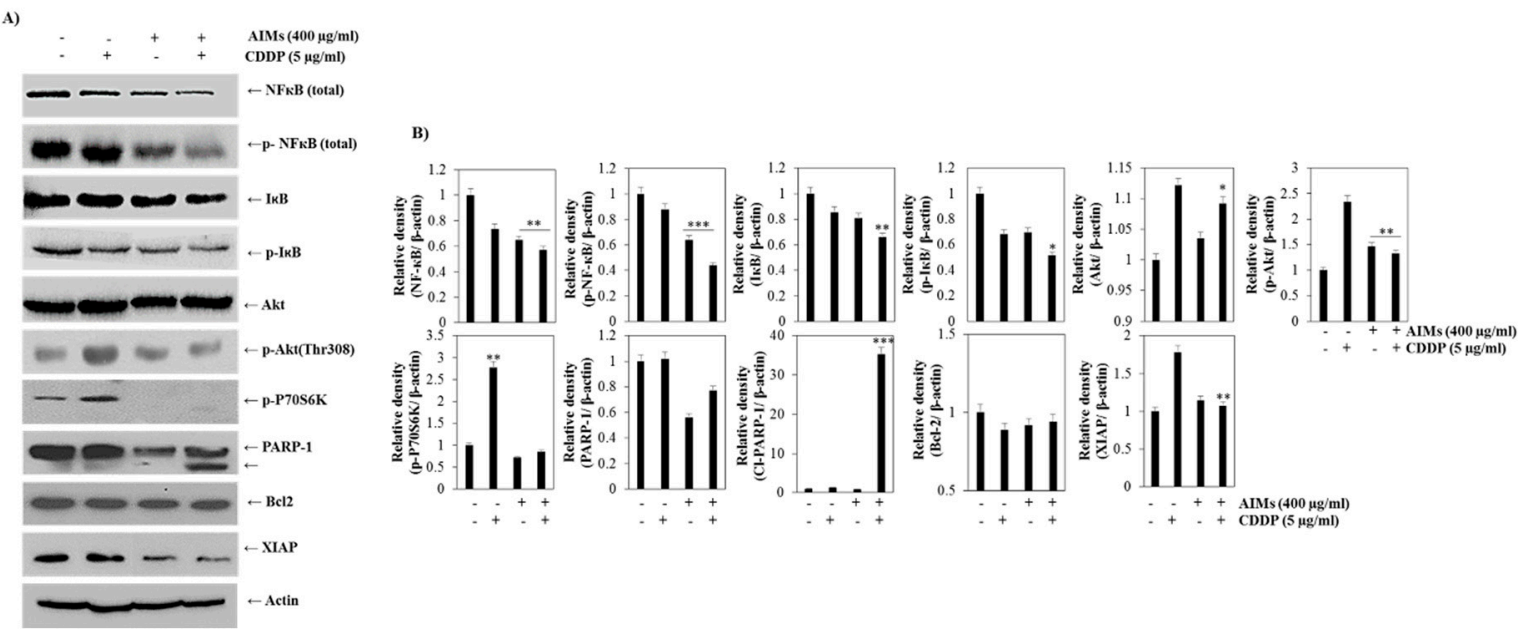

Figure 4. The effect of CDDP with or without AIMs on NF- $\mathrm{kB}$ activity in MCF-7 cells. The proteins were isolated from MCF-7 cells treated with $400 \mu \mathrm{g} / \mathrm{mL}$ of AIMs and $5 \mu \mathrm{g} / \mathrm{mL}$ of CDDP for $48 \mathrm{~h}$. (A) Equal amounts of cell lysate $(30 \mu \mathrm{g})$ were resolved by SDS polyacrylamide gels and transferred onto nitrocellulose membranes. The membranes were probed with the indicated antibodies and detected by the enhanced chemiluminescence detection system. Western blot analysis for Akt, NF- $\mathrm{kB}$ and NF- $\kappa B$ regulated proteins. The data shown here are representative of at least three independent experiments. (B) Densitometry analysis of Western blot bands. The values were normalized against actin and expressed as a mean of \pm SD of at least three independent experiments ${ }^{*} p<0.05, * * p<0.01$, and ${ }^{* * *} p<0.0001$ between control and treated groups. "+" and "absence of the compound, absence of the compound specified.

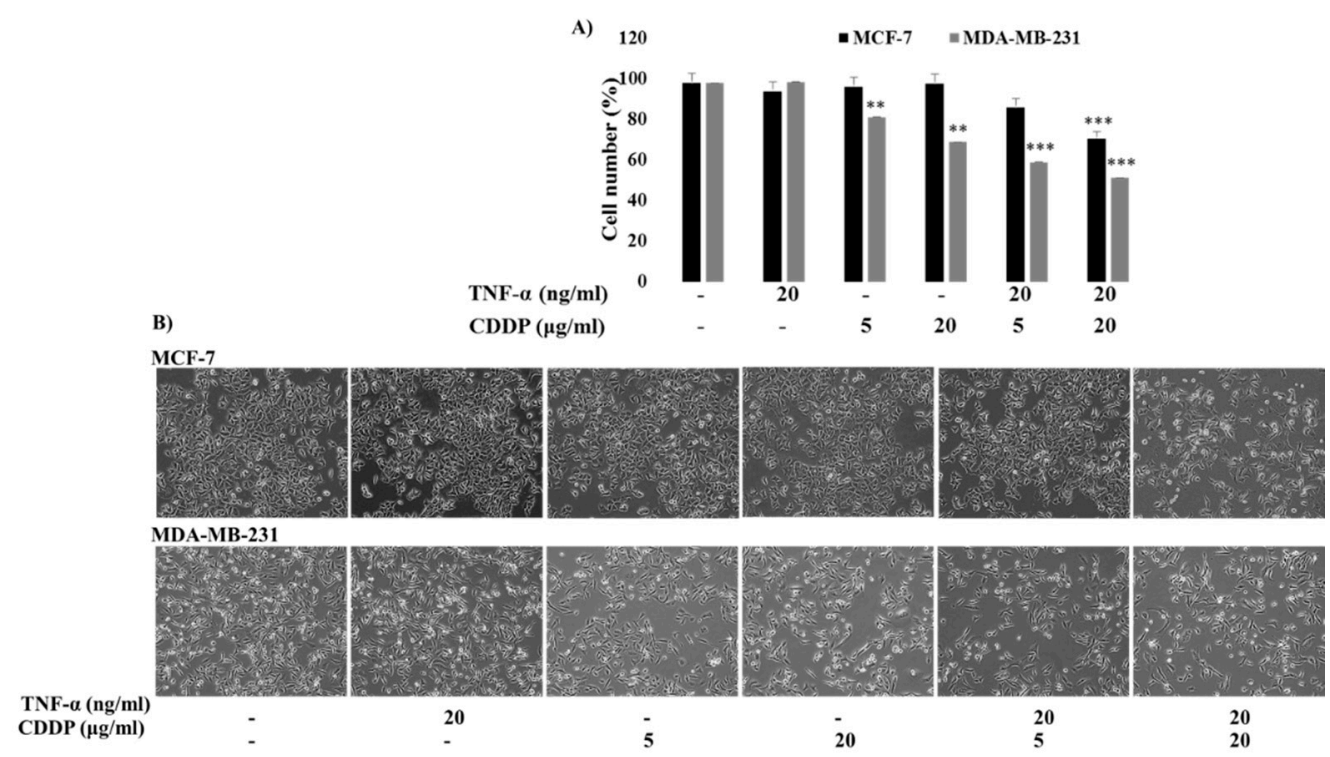

Figure 5. The effect of combination treatment of TNF- $\alpha$ and CDDP on MCF-7 and MDA-MB-231 cells. (A) The cell viability is measured by the trypan blue exclusion assay. MCF-7 and MDA-MB-231 cells were pre-treated with $20 \mathrm{ng} / \mathrm{mL}$ of TNF- $\alpha 1 \mathrm{~h}$ at $37^{\circ} \mathrm{C}$ followed by the treatment of 5 and $20 \mu \mathrm{g} / \mathrm{mL}$ of CDDP. The cells were stained with trypan blue and counted using a haemocytometer and percentage of viable cells were calculated. (B) The morphological representation of TNF- $\alpha$ treated MCF-7 and MDA-MB-231 cells with CDDP. The cells were pre-treated with $20 \mathrm{ng} / \mathrm{mL}$ of TNF- $\alpha 1 \mathrm{~h}$ at $37^{\circ} \mathrm{C}$ followed by the treatment of 5 and $20 \mu \mathrm{g} / \mathrm{mL}$ of CDDP. The data shown are mean \pm SD of three different experiments performed separately. ${ }^{* *} p<0.05$ versus treated group and ${ }^{* *} p<0.05$ versus CDDP treated group. "-" represents the absence of the compound, absence of the compound specified. 
2.6. AIMs Significantly Enhanced the Effects of TNF- $\alpha$ Alone and Combination Treatment of TNF- $\alpha$ and $C D D P$

Then, we assessed the effects of AIMs on MCF-7 cells treated with TNF- $\alpha$ and CDDP. AIMs significantly suppressed cell viability of MCF-7 cells treated with TNF- $\alpha$ alone and TNF- $\alpha$ and CDDP together (Figure 6A). There were synergistic effects between AIMs and TNF- $\alpha$ alone or TNF- $\alpha$ and CDDP; AIMs with TNF- $\alpha$ alone and with TNF- $\alpha$ and CDDP in combination induced $25 \%$ and $16 \%$ cell viability of MCF-7 cells, respectively (Figure 6B). This finding suggests that AIMs enhances anti-cancer effects by inhibiting NF- $\kappa \mathrm{B}$ activation because TNF- $\alpha$ is a known NF- $\mathrm{B}$ stimulant and its anti-cancer effects were not clearly observed by NF- $\mathrm{B}$ activation [28]. To confirm this finding at molecular level, we performed Western blot analysis. It revealed that $6 \mathrm{~h}$ and $12 \mathrm{~h}$ treatment of TNF- $\alpha$ significantly induced NF- $\mathrm{B}$ activation, and its effect was inhibited by AIMs in MCF-7 cells (Figure 6E). These findings suggested that AIMs ameliorate CDDP efficacy by inhibiting NF- $\mathrm{B}$ activation in MCF-7 cells. Figure 7 shows the schematic diagram of the AIMs and the CDDP effect on MCF-7 breast cancer cells. 

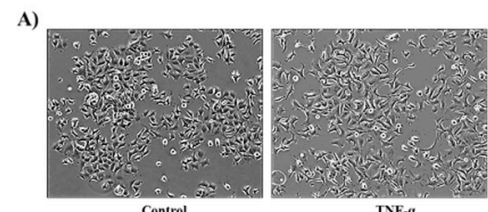

TNF $\cdot a$

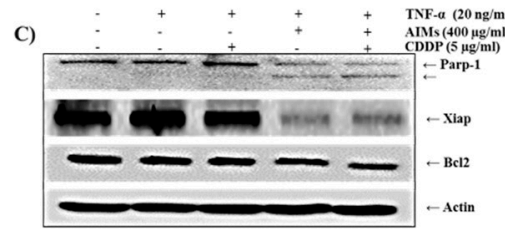

D)

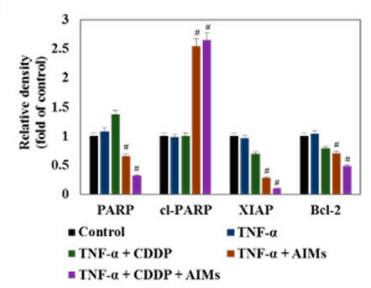

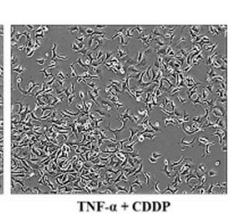
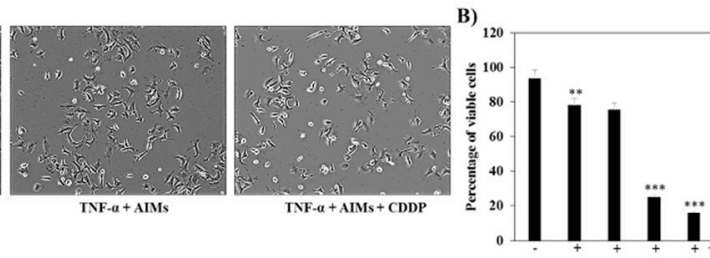

TNF- $\alpha+$ AIMs

TNF- $a+$ AIMs + CD

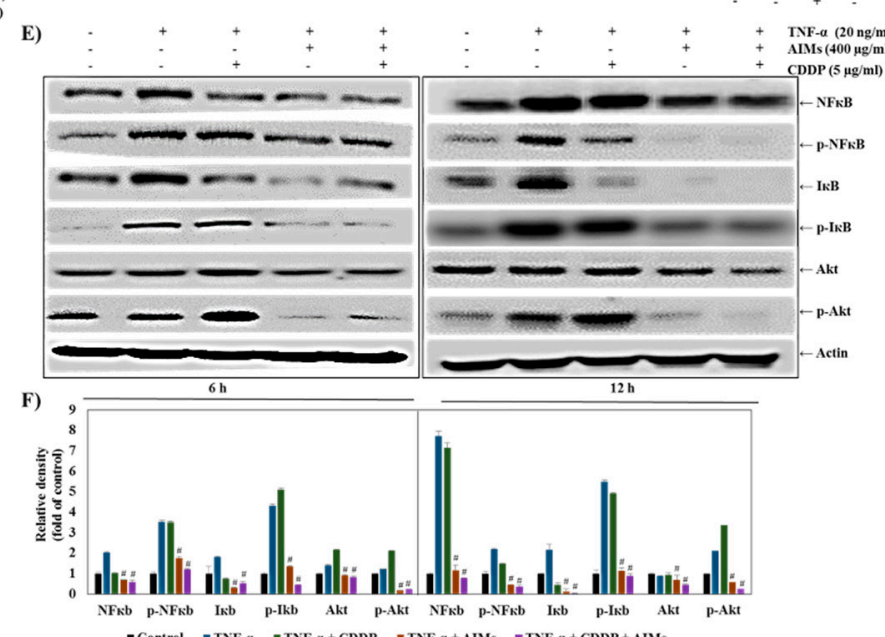

Figure 6. The inhibitory effects of AIMs on MCF-7 cells treated with TNF- $\alpha$ and CDDP treatment. (A) the morphological representation of TNF- $\alpha$ treated cells with AIMs and CDDP. MCF-7 cells were pretreated with $400 \mu \mathrm{g} / \mathrm{mL}$ of AIMs $1 \mathrm{~h}$ at $37^{\circ} \mathrm{C}$, subsequently treated with or without $5 \mu \mathrm{g} / \mathrm{mL}$ of CDDP and $20 \mathrm{ng} / \mathrm{mL}$ of TNF- $\alpha$ at $37^{\circ} \mathrm{C}$, incubated for $48 \mathrm{~h}$. (B) The cell viability is measured by the trypan blue exclusion assay. The data shown are mean \pm SD of three different experiments performed separately. ${ }^{* *} p<0.05$ non-treated versus treated group and ${ }^{* * *} p<0.05$ TNF- $\alpha$ treated versus AIMs and CDDP treated group. (C) Western blot analysis for cytotoxic effect of TNF- $\alpha$, AIMs, and CDDP combined treatment for $48 \mathrm{~h}$. The total lysates of MCF-7 cells with the above-mentioned treatment were resolved on SDS-polyacrylamide gels followed by transfer to PVDF membrane and probed with the specific primary and secondary antibody. The protein was visualized using chemidoc with the ECL detection kit. The data shown here are representative of at least three independent experiments. (D) The densitometry analysis of Western blot bands was normalized against actin and expressed as a mean of \pm SD of at least three independent experiments $\# p<0.05$ TNF- $\alpha$ treated versus AIMs and CDDP treated group; (E) Western blot analysis of time dependent TNF- $\alpha$ treatment. MCF-7 cells were treated with $400 \mathrm{AIMs} \mu \mathrm{g} / \mathrm{mL}$ of AIMs for $1 \mathrm{~h}$ at $37^{\circ} \mathrm{C}$, subsequently treated with or without $5 \mu \mathrm{g} / \mathrm{mL}$ of CDDP and $20 \mathrm{ng} / \mathrm{mL}$ of TNF- $\alpha$ for $6 \mathrm{~h}$ and $12 \mathrm{~h}$ at $37^{\circ} \mathrm{C}$. The total lysates of MCF-7 cells with the above-mentioned treatment were resolved on SDS-polyacrylamide gels followed by transfer to PVDF membrane and probed with the specific primary and secondary antibody. The protein was visualized using chemidoc with the ECL detection kit. The data shown here are representative of at least two independent experiments. (F) The densitometry analysis of Western blot bands was normalized against actin and expressed as a mean of \pm SD of at least three independent experiments $\# p<0.05 \mathrm{TNF}-\alpha$ treated versus AIMs and the CDDP treated group. " + " and "-" represents the presence and absence of the compound, absence of the compound specified. 


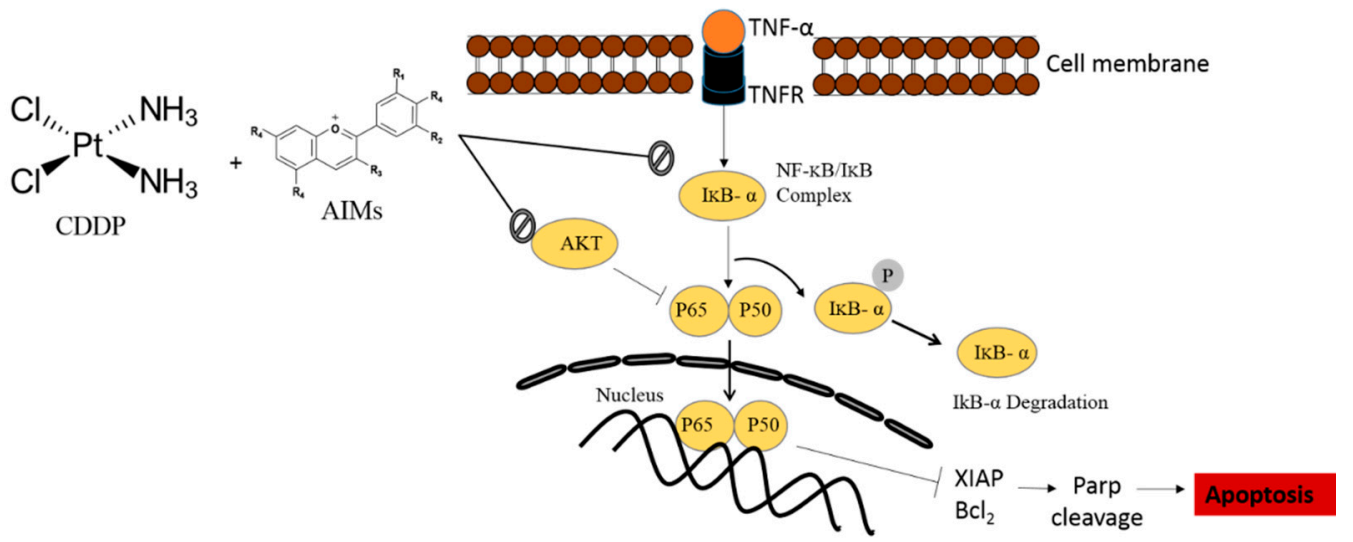

Figure 7. The schematic diagram representing AIMs potentiating CDDP sensitivity through NF- $\mathrm{KB}$ inhibition. In this study, CDDP resistance of MCF-7 cells was at least in part involved in Akt activation and NF- $\mathrm{KB}$ activation; CDDP significantly increased p-Akt and followed by maintaining $\mathrm{p}-\mathrm{NF}-\kappa \mathrm{B}$, and $\mathrm{p}-\mathrm{I} \kappa \mathrm{B}$ which are usually suppressed by CDDP in CDDP-sensitive cancer cells [15]. AIMs inhibited CDDP-induced Akt activation and suppressed maintained NF- $\mathrm{B}$ activity. Through these two mechanisms, AIMs enhanced CDDP efficacy of MCF-7 cells that showed relative resistance by $X$-linked inhibitor of apoptosis protein (XIAP). AIMs contains the following composition; delphinidin-3,5-diglucoside:cyanidin-3,5-diglucoside:petunidin-3,5-diglucoside:delphinidin-3-glucoside: malvdin-3,5-diglucoside:peonidin-3,5-diglucoside: cyanidin-3-glucoside:petunidin-3-glucoside:peonidin-3glucoside:malvidin-3-glucoside $\frac{1}{4}$ 1.0:0.5:3.4:28.1:6.4:6.4:4.2: 2.5:4.9:22.5:5.0:22.6.

\section{Discussion}

In this study, we postulated that the AIMs can enhance the effect of CDDP by the inhibition of NF- $\mathrm{KB}$ and Akt signaling on MCF-7 cells that showed intrinsic CDDP resistance. We found that AIMs significantly enhance the efficacy of CDDP on MCF-7 cells by inhibiting CDDP-induced Akt activation and maintained NF- $\mathrm{KB}$ activity while on CDDP treatment. It was reported that CDDP inhibits significantly NF- $\kappa B$ activity by suppressing $\mathrm{p}-\mathrm{I} \kappa \mathrm{B}$ in CDDP-sensitive cancer cells and that an inhibitor of NF- $\mathrm{KB}$ that blocks I $\kappa \mathrm{B}$ phosphorylation showed overcome relative CDDP resistance, even though CDDP usually suppresses NF-kB activity in cancer cells [19,29].

We recently demonstrated that AIMs served as an inhibitor of NF-KB in MCF-7 cells [28]. NF- $\mathrm{kB}$ activation involved in drug resistance by suppressing pro-apoptotic and inducing anti-apoptotic molecules [30,31]. Most of the previous studies of AIMs showed predominantly anti-cancer activity by inhibiting NF- $\mathrm{KB}$ and NF- $\mathrm{kB}$-regulated proteins involved in apoptosis, angiogenesis, and metastasis [28,32]. In addition, there are reports that CDDP resistance was reversed by an NF-KB inhibitor; in that study, an NF- $\mathrm{kB}$ inhibitor, BAY 117,085 augmented CDDP effects by suppressing the expression of XIAP. This finding is consistent with our result. In addition, a soy isoflavone, genistein, increased CDDP sensitivity by inhibiting NF- $\mathrm{kB}$ activity in pancreatic cancer cells [33]. Furthermore, evidence suggests that NF- $\mathrm{KB}$ and Akt activation is one of the major causes to attain CDDP resistance in cancer cells [31]. These findings all support that AIMs could enhance the efficacy of CDDP on MCF-7 cells by inhibiting NF- $\mathrm{kB}$ and an NF- $\mathrm{kB}$-regulated protein, XIAP.

However, the NF- $\mathrm{kB}$ signaling cascade is also one of the downstream signals of the PI3K/AKT pathway, activation of Akt promotes IKB degradation via phosphorylating IKK $\alpha$ kinase [17]. In MCF-7 cells, some may think that inhibition of Akt would be the main mechanism for boosting CDDP efficacy because AIMs clearly inhibited the activation of Akt that was induced by CDDP (Figure 4) and that Akt regulates NF- $\mathrm{kB}$ by suppressing IкB degradation and also promotes cancer cell survival by activating anti-apoptotic proteins and inactivating pro-apoptotic proteins [34]. We also agreed in some part because AIMs showed anti-cancer effects by inhibition of Akt activity [35]. However, with AIMs effects on Akt, it is hard to explain the synergistic effect between TNF- $\alpha$ and CDDP; TNF- $\alpha$ in combination with 
AIMs with or without CDDP exhibited a remarkable anti-cancer effect with high efficacy on reducing cell viability (Figure 6). In addition, cancer cells with no NF- $\kappa$ B activity showed high sensitivity to TNF- $\alpha$ treatment and other chemotherapeutic drugs [36]. These findings support that AIM effects on CDDP also should be attributed to inhibition of NF- $\kappa B$ at least in part.

Regarding chemotherapeutic strategy, many researchers were interested in NF- $\mathrm{KB}$ inhibitors rather than Akt inhibitors even though the direct cause of CDDP resistance appeared to be up-regulation of Akt $[18,19]$. The reason would be the toxicities of Akt inhibitors; Akt signaling plays a critical role in maintaining normal cell homeostasis. As previously shown, AIMs $400 \mu \mathrm{g} / \mathrm{mL}$ of AIMs did not show toxicity to normal cells [28]. These findings suggest that AIMs inhibit Akt signaling indirectly, probably upstream target molecules. As supporting evidence, a certain anthocyanin directly binds to EGFR and AIMs also inhibit EGFR and non-EGFR related Akt signaling [37]. This finding suggests that only under EGFR high expression do anthocyanins serve as a signaling inhibitor and that the toxicity would be insignificant. In addition, most previous studies of AIMs showed predominantly anti-metastatic activity by inhibiting Akt or NF- $\mathrm{BB}$ and its downstream molecules with moderate inhibition of cell proliferation rather than cell killing [32]. These findings suggest that the addition of AIMs to CDDP treatment is a safe strategy to enhance CDDP efficacy on cancer cells.

The limitations of the study are as follows. First, this study did not clearly demonstrate that how AIMs inhibit Akt or NF-kB signaling regarding the enhancing effects of AIMs on CDDP efficacy of MCF-7 cells as well as which signaling is more important in enhancing CDDP efficacy. Many reports demonstrated that natural polyphenols including anthocyanin also modulate Akt signaling pathways to inactivate the NF- $\mathrm{BB}$, and STAT3 in cancers [38-40], but it is not fully elucidated how these natural polyphenols are suppressing these signaling cascades. It is still unknown whether they bind directly or upstream kinases or directly binding key proteins. Therefore, additional studies are required to address these questions.

Secondly, we used an NF-kB stimulator, TNF- $\alpha$ to clearly answer whether the effects of AIMs on CDDP resistance is related to inhibition of NF- $\kappa B$ in MCF-7 cells. The cytokine family, tumor necrosis factor- $\alpha(\mathrm{TNF}-\alpha)$, has a versatile function involving many physiological signaling [41]. TNF- $\alpha$ is a potent pleiotropic pro-inflammatory cytokine produced by macrophages, neutrophils, fibroblasts, keratinocytes, NK cells, T and B lymphocytes, and tumor cells [42]. Studies have shown that MCF-7 cells are vulnerable to high doses of TNF- $\alpha$ treatment [43], while some studies revealed that low doses of TNF- $\alpha$ treatment (20 ng/mL) may induce cell proliferation in MCF-7 cells [42]. We initially chose a low dose as an NF-кB inhibitor, but it induced anti-cancer effects on MCF-7 cells. Literature suggests that TNF- $\alpha$ can induce both apoptosis and inhibit apoptosis through NF- $\kappa B$ activation in cancer cells [44-46]. In the present study, we showed $20 \mathrm{ng} / \mathrm{mL}$ of TNF- $\alpha$ treatment with AIMs, and with or without CDDP, it increased the anti-cancer activities. The use of TNF- $\alpha$ is applicable for the patients with cancer with resistance because the level of TNF- $\alpha$ is highly increased in patients with advanced and metastatic cancer, and it is associated with cancer progression $[47,48]$. This study showed that TNF- $\alpha$ shows a synergistic effect with AIMs, and it can be used as a therapeutic tool by inhibiting NF- $\kappa$ B activity in platinum drug resistant cancers.

Lastly, the concentration of the AIMs used in this study seemed to be high for in-vivo studies due to toxicity. However, AIMs did not demonstrate toxicity to normal cells, and in vivo studies with different concentrations of AIMs have already been reported [49]. The present study is also in line with the other studies which showed the anti-cancer properties of anthocyanin in vitro [13,50,51].

In conclusion, AIMs enhanced CDDP sensitivity by inhibiting Akt and NF- $\mathrm{kB}$ activity of MCF-7 cells that show relative intrinsic CDDP resistance. This study provides evidence that the addition of AIMs to CDDP would an alternative option for a combination of TNF- $\alpha$ inhibitor and CDDP in human breast cancer. 


\section{Material and Methods}

\subsection{Cell Culture and Chemicals}

MDA-MB-231 and MCF-7 human breast cancer cell lines from ATCC were cultured in RPMI-1640 (Hyclone, Waltham, MA, USA) with 10\% fetal bovine serum heat (FBS, Gibco-BRL, Grand Island, NY, USA) inactivated at $56^{\circ} \mathrm{C}$ for $45 \mathrm{~min} 1 \mathrm{mM}$ L-glutamine, $100 \mathrm{U} / \mathrm{mL}$ penicillin, and $100 \mu \mathrm{g} / \mathrm{mL}$ streptomycin at $37^{\circ} \mathrm{C}$, in $\mathrm{CO}_{2}$ Incubator. Protein molecular markers were obtained from Geneaid (New Taipei City, Taiwan). Primary antibodies, NF-kB, p- NF-kB, FAS, Akt, p-Akt, Bcl-2, Bax, p53, XIAP, Parp-1 were acquired from Santa-Cruz Biotechnology Inc. (Santa Cruz, CA, USA). IkB, p-IкB were purchased from cell signaling technologies Inc. (Beverley, MA, USA). The $\beta$-actin antibody was purchased from Sigma (Beverley, MA, USA). Secondary antibodies (anti-mouse, anti-rabbit, anti-goat) purchased from Bethyl laboratories, enhanced chemiluminescence (ECL) kit was purchased from Amersham (Arlington Heights, IL, USA). The chemicals which are not specified here are purchased from Sigma Chemical Co. (St.Louis, MO, USA).

\subsection{AIM Preparation}

AIMs were extracted from the fruits of Meoru. The well matured Meoru fruits were collected at Jiri Mountain, Republic of Korea. Purification and characterization of AIMs (Anthocyanins In Meoru) were described previously [52]. Briefly, Anthocyanin pigments were extracted by maceration of the fruits (100 g) in methanol containing $0.1 \% \mathrm{HCl}$ at $5{ }^{\circ} \mathrm{C}$ for $24 \mathrm{~h}$. The extraction procedure was repeated three times. After concentration under reduced pressure (Rotavapor R-124, Buchi, Flawil, Switzerland), the extract was diluted with distilled water $(100 \mathrm{~mL})$ and partitioned against ethyl acetate $(3(100 \mathrm{~mL})$. The water layer containing the pigments was concentrated to $50 \mathrm{~mL}$. The concentrate was purified according to established procedures by means of ethyl acetate/water partitioning and adsorption chromatography on a bed of Amberlite XAD-7 (Sigma, Youngin, Korea). AIM contains the following composition; delphinidin-3,5-diglucoside:cyanidin-3,5-diglucoside:petunidin-3,5-diglucoside:delphinidin-3-glucoside: malvdin-3,5-diglucoside:peonidin-3,5-diglucoside: cyanidin-3-glucoside:petunidin-3-glucoside:peonidin3-glucoside:malvidin-3-glucoside 1/4 1.0:0.5:3.4:28.1:6.4:6.4:4.2: 22.5:4.9:22.5:5.0:22.6.

\subsection{Trypan Blue Exclusion Assay}

Trypan blue staining is used to identify the number of viable and dead cells. The cells were seeded in 6-well plates with the seeding density of $5 \times 10^{4}$ cells/well. After the indicated amount of drug treatment, the cells were incubated for $48 \mathrm{~h}$ at $37^{\circ} \mathrm{C}$ in a $\mathrm{CO}_{2}$ incubator. The cells were trypsinized and collected with the floating cells. After centrifugation, the cells were dissolved in $50 \mu \mathrm{L}$ of media. In addition, $50 \mu \mathrm{L}$ of $0.4 \%$ trypan blue (Sigma, Beverley, MA, USA) was added and then counted under a light microscope within 5 min using a hemocytometer. The percentage of viable cells is calculated as (1-(Number of dead cells/Number of total cells)) $\times 100$.

\subsection{DAPI Staining}

The cells were seeded in 12 well plates with a density of $1 \times 10^{5}$ cells/well and grown for $48 \mathrm{~h}$ with the indicated drug treatment at $37^{\circ} \mathrm{C}$ in a $\mathrm{CO}_{2}$ incubator. After treatment, the media were removed and cells were washed with 1 X PBS three times. The cells were fixed with a $4 \%$ formaldehyde solution in $4{ }^{\circ} \mathrm{C}$ for overnight. After incubation, the cells were washed with $1 \mathrm{X}$ PBS thrice. One microliter of $1 \mu \mathrm{g} / \mathrm{mL}$ DAPI was added to $1 \mathrm{~mL}$ of 1 X PBS. The cells were kept at $37^{\circ} \mathrm{C}$ for $1 \mathrm{~h}$. After $1 \mathrm{~h}$ incubation, the cells were washed with 1 X PBS for three times, and $200 \mu \mathrm{L}$ of $90 \%$ glycerol was added and analyzed under the fluorescent microscope. 


\subsection{Cell Cycle Analysis through Flow Cytometry (PI Staining)}

The MCF-7 cells were seeded in 6-well plates with a density of $5 \times 10^{4}$ cells/well and treated with the indicated concentration. After $48 \mathrm{~h}$ of treatment, the cells were trypsinized and collected with the floating media in a $15 \mathrm{~mL}$ falcon tube and centrifuged at $2000 \mathrm{rpm}$ for $5 \mathrm{~min}$. The supernatant was removed and washed with $5 \mathrm{~mL}$ of 1 X PBS twice. The pellet was suspended in $300 \mu \mathrm{L}$ of 1 X PBS and later added with $700 \mu \mathrm{L}$ of absolute ethanol. The pellet was shifted to a $1.5 \mathrm{~mL}$ Eppendorf tube and fixed for $20 \mathrm{~min}$ in $-20^{\circ} \mathrm{C}$. After fixing, the cells were centrifuged and the pellet was suspended in $500 \mu \mathrm{L}$ of 1 X PI containing $50 \mu \mathrm{g} / \mathrm{mL}$ PI in 1 X PBS and $50 \mu \mathrm{g}$ of RNase A followed by incubation in dark for $20 \mathrm{~min}$. After incubation, flow cytometry analyses were performed by Cytomics FC 500 (Beckman Coulter, Brea, CA, USA). The data were analyzed in CXP Software (Beckman Coulter, Inc., Fullerton, CA, USA).

\subsection{Apoptosis Analysis through Annexin V and PI Staining}

Apoptosis cell detection was performed using FITC Annexin V Apoptosis Detection Kit I (BD Pharmingen, San Diego, CA, USA). As per the manufacturer protocol, after treatment, the cells trypsinized and washed with 1 X PBS were re-suspended in $100 \mu \mathrm{L}$ of binding buffer and stained with $10 \mu \mathrm{L}$ of Annexin V-FITC and $10 \mu \mathrm{L}$ PI. The stained cells were incubated for $30 \mathrm{~min}$ in dark. After incubation, FACS (Flow cytometry) analysis was performed using Cytomics FC 500 (Beckman Coulter, Brea, CA, USA). The data were analyzed in CXP Software (Beckman Coulter, Inc., Fullerton, CA, USA).

\subsection{Western Blot Analysis}

MCF-7 breast cancer cell lines were seeded in a $10 \mathrm{~cm}$ dish plate with a seeding density of $2.2 \times 10^{6}$ cells/well. AIMs were treated for $48 \mathrm{~h}$ with a concentration of $400 \mu \mathrm{g} / \mathrm{mL}$ and CDDP was treated with a concentration of $5 \mu \mathrm{g} / \mathrm{mL}$. For combined treatment, AIMs were treated $1 \mathrm{~h}$ before the treatment of CDDP. For TNF- $\alpha$ treatment, $20 \mathrm{ng}$ was treated $1 \mathrm{~h}$ before the treatment of AIMs and then CDDP. After treatment, the cells were collected by the use of cell scraper and then centrifuged at $2000 \mathrm{rpm}$ for $5 \mathrm{~min}$. The supernatant was removed and centrifuged again to remove the excess media. After complete removal of the media, the pellet was suspended in $500 \mu \mathrm{L}$ of $2 \mathrm{X}$ sample buffer (100 mM of Tris- $\mathrm{Cl}$ ( $\mathrm{pH} 6.8), 4 \%$ (w/v) sodium dodecyl sulphate (SDS), $0.2 \%(w / v)$ Bromophenol blue and $200 \mathrm{mM}$ of DTT (dithiothreitol). The protein lysates were collected in the $1.5 \mathrm{~mL}$ Eppendorf tubes and kept at $100{ }^{\circ} \mathrm{C}$ for $10 \mathrm{~min}$. The protein was quantified using Bradford assay. In addition, $30 \mu \mathrm{g}$ of proteins were resolved in 8-12\% SDS-PAGE and followed by the transfer to PVDF (polyvinylidene difluoride) membrane. After transfer, the membranes were blocked with 3\% skimmed milk in TBST buffer (Tris-buffered saline containing 1\% Tween 20) for $30 \mathrm{~min}$ at room temperature and incubated at $4{ }^{\circ} \mathrm{C}$ for overnight with primary antibodies. After overnight incubation, the membranes were washed with TBST buffer thrice each wash for about $10 \mathrm{~min}$ followed by the incubation with 1:2000 dilution of horseradish peroxidase (HRP)-conjugated secondary antibody for $1 \mathrm{~h}$ in room temperature. The membranes were later washed with TBST buffer for three times (10 $\mathrm{min} /$ wash) subsequently developed with ECL (electrochemiluminescence) solutions (Bio-Rad Laboratory, Hercules, CA, USA).

\subsection{Statistical Analysis}

All experiments were performed in triplicated and the results were expressed as means \pm standard deviation (SD). A Student's $t$-test using SPSS Version 10.0 for Windows (SPSS, Chicago, IL, USA) is used for two-group comparisons, and for three treatment groups, one-way analysis variance with Newman-Kuels is used to calculate the significance. The synergetic index was calculated as previously reported [20] if $\frac{\text { Percentage of } A B}{\text { Percentage of } A \times \text { Percentage of } B}<1$ it denotes synergism, if $\frac{\text { Percentage of } A B}{\text { Percentage of } A \times \text { Percentage of } B}$ $=1$ it denotes additive effect, if $\frac{\text { Percentage of } A B}{\text { Percentage of } A \times \text { Percentage of } B}>1$ it denotes antagonism. In the given equations, $A$ and $B$ is the effect of the drug individually and $A B$ is the combined effect. 
Author Contributions: A.P., M.J.K., and W.S.L. designed the study protocol, performed all of the experiments, organized the focus group discussion, collected, analyzed all study data, and prepared the final manuscript. H.J.K. and E.J.J. participated in the focus group discussion and collection of data and contributed to the manuscript writing. S.-H.C., S.C.H., J.-M.J., S.C.S. and G.S.K. revised the study design and contributed to the statistical analysis and editing of the manuscript. All authors have read and agreed to the published version of the manuscript.

Funding: This work was supported by the grants from the National R\&D Program for Cancer Control, Ministry of Health \& Welfare, Republic of Korea (0820050), and in part Basic Science Research Program through the National Research Foundation of Korea (NRF) funded by the Ministry of Education (2017R1D1A3B05030971).

Conflicts of Interest: The authors declare no conflict of interest. All authors have read and agreed to the published version of the manuscript.

\section{References}

1. Zaheer, S.; Shah, N.; Maqbool, S.A.; Soomro, N.M. Estimates of past and future time trends in age-specific breast cancer incidence among women in Karachi, Pakistan: 2004-2025. BMC Public Health 2019, 19, 1001. [CrossRef] [PubMed]

2. Jung, K.-W.; Won, Y.-J.; Kong, H.-J.; Lee, E.S. Cancer Statistics in Korea: Incidence, Mortality, Survival, and Prevalence in 2016. Cancer Res. Treat. 2019, 51, 417-430. [CrossRef] [PubMed]

3. Housman, G.; Byler, S.; Heerboth, S.; Lapinska, K.; Longacre, M.; Snyder, N.; Sarkar, S. Drug resistance in cancer: An overview. Cancers 2014, 6, 1769-1792. [CrossRef] [PubMed]

4. Van der Jeught, K.; Xu, H.C.; Li, Y.J.; Lu, X.B.; Ji, G. Drug resistance and new therapies in colorectal cancer. World J. Gastroenterol. 2018, 24, 3834-3848. [CrossRef]

5. Fichtinger-Schepman, A.M.; van der Veer, J.L.; den Hartog, J.H.; Lohman, P.H.; Reedijk, J. Adducts of the antitumor drug cis-diamminedichloroplatinum(II) with DNA: Formation, identification, and quantitation. Biochemistry 1985, 24, 707-713. [CrossRef]

6. Zwelling, L.A.; Anderson, T.; Kohn, K.W. DNA-protein and DNA interstrand cross-linking by cis- and trans-platinum(II) diamminedichloride in L1210 mouse leukemia cells and relation to cytotoxicity. Cancer Res. 1979, 39, 365-369.

7. Zhuo, W.; Wang, Y.; Zhuo, X.; Zhang, Y.; Ao, X.; Chen, Z. Knockdown of Snail, a novel zinc finger transcription factor, via RNA interference increases A549 cell sensitivity to cisplatin via JNK/mitochondrial pathway. Lung Cancer 2008, 62, 8-14. [CrossRef]

8. Johnson, S.W.; Laub, P.B.; Beesley, J.S.; Ozols, R.F.; Hamilton, T.C. Increased platinum-DNA damage tolerance is associated with cisplatin resistance and cross-resistance to various chemotherapeutic agents in unrelated human ovarian cancer cell lines. Cancer Res. 1997, 57, 850-856.

9. Kumar Biswas, S.; Huang, J.; Persaud, S.; Basu, A. Down-regulation of Bcl-2 is associated with cisplatin resistance in human small cell lung cancer H69 cells. Mol. Cancer 2004, 3, 327-334.

10. Siddik, Z.H. Cisplatin: Mode of cytotoxic action and molecular basis of resistance. Oncogene 2003, 22, 7265-7279. [CrossRef]

11. Cojocneanu Petric, R.; Braicu, C.; Raduly, L.; Zanoaga, O.; Dragos, N.; Monroig, P.; Dumitrascu, D.; Berindan-Neagoe, I. Phytochemicals modulate carcinogenic signaling pathways in breast and hormone-related cancers. Oncotargets Ther. 2015, 8, 2053-2066. [CrossRef] [PubMed]

12. Zhou, Y.; Zheng, J.; Li, Y.; Xu, D.P.; Li, S.; Chen, Y.M.; Li, H.B. Natural Polyphenols for Prevention and Treatment of Cancer. Nutrients 2016, 8. [CrossRef] [PubMed]

13. Koide, T.; Kamei, H.; Hashimoto, Y.; Kojima, T.; Hasegawa, M. Antitumor effect of hydrolyzed anthocyanin from grape rinds and red rice. Cancer Biother. Radiopharm. 1996, 11, 273-277. [CrossRef] [PubMed]

14. Lin, B.W.; Gong, C.C.; Song, H.F.; Cui, Y.Y. Effects of anthocyanins on the prevention and treatment of cancer. Br. J. Pharmacol. 2017, 174, 1226-1243. [CrossRef] [PubMed]

15. Shin, D.Y.; Lee, W.S.; Lu, J.N.; Kang, M.H.; Ryu, C.H.; Kim, G.Y.; Kang, H.S.; Shin, S.C.; Choi, Y.H. Induction of apoptosis in human colon cancer HCT-116 cells by anthocyanins through suppression of Akt and activation of p38-MAPK. Int. J. Oncol. 2009, 35, 1499-1504. [CrossRef] [PubMed]

16. Yun, J.W.; Lee, W.S.; Kim, M.J.; Lu, J.N.; Kang, M.H.; Kim, H.G.; Kim, D.C.; Choi, E.J.; Choi, J.Y.; Lee, Y.K.; et al. Characterization of a profile of the anthocyanins isolated from Vitis coignetiae Pulliat and their anti-invasive activity on HT-29 human colon cancer cells. Food Chem. Toxicol. 2010, 48, 903-909. [CrossRef] 
17. Thévenod, F.; Friedmann, J.M.; Katsen, A.D.; Hauser, I.A. Up-regulation of multidrug resistance P-glycoprotein via nuclear factor-kappaB activation protects kidney proximal tubule cells from cadmiumand reactive oxygen species-induced apoptosis. J. Biol. Chem. 2000, 275, 1887-1896. [CrossRef]

18. Ruan, H.Y.; Masuda, M.; Ito, A.; Umezawa, K.; Nakashima, T.; Yasumatsu, R.; Kuratomi, Y.; Yamamoto, T.; Weinstein, I.B.; Komune, S. Effects of a novel NF-kappaB inhibitor, dehydroxymethylepoxyquinomicin (DHMEQ), on growth, apoptosis, gene expression, and chemosensitivity in head and neck squamous cell carcinoma cell lines. Head Neck 2006, 28, 158-165. [CrossRef]

19. Mabuchi, S.; Ohmichi, M.; Nishio, Y.; Hayasaka, T.; Kimura, A.; Ohta, T.; Saito, M.; Kawagoe, J.; Takahashi, K.; Yada-Hashimoto, N.; et al. Inhibition of NFkappaB increases the efficacy of cisplatin in in vitro and in vivo ovarian cancer models. J. Biol. Chem. 2004, 279, 23477-23485. [CrossRef]

20. Bray, F.; Ferlay, J.; Soerjomataram, I.; Siegel, R.L.; Torre, L.A.; Jemal, A. Global cancer statistics 2018: GLOBOCAN estimates of incidence and mortality worldwide for 36 cancers in 185 countries. Ca A Cancer J. Clin. 2018, 68, 394-424. [CrossRef]

21. Yang, W.; Soares, J.; Greninger, P.; Edelman, E.J.; Lightfoot, H.; Forbes, S.; Bindal, N.; Beare, D.; Smith, J.A.; Thompson, I.R.; et al. Genomics of Drug Sensitivity in Cancer (GDSC): A resource for therapeutic biomarker discovery in cancer cells. Nucleic Acids Res. 2013, 41, D955-D961. [CrossRef] [PubMed]

22. Nagata, S. Apoptosis by death factor. Cell 1997, 88, 355-365. [CrossRef]

23. Yde, C.W.; Issinger, O.G. Enhancing cisplatin sensitivity in MCF-7 human breast cancer cells by down-regulation of Bcl-2 and cyclin D1. Int. J. Oncol. 2006, 29, 1397-1404. [CrossRef] [PubMed]

24. Goldstein, D.; Bushmeyer, S.M.; Witt, P.L.; Jordan, V.C.; Borden, E.C. Effects of type I and II interferons on cultured human breast cells: Interaction with estrogen receptors and with tamoxifen. Cancer Res. 1989, 49, 2698-2702. [PubMed]

25. Eichholtz-Wirth, H.; Sagan, D. IkappaB/NF-kappaB mediated cisplatin resistance in HeLa cells after low-dose gamma-irradiation is associated with altered SODD expression. Apoptosis Int. J. Program. Cell Death 2000, 5, 255-263. [CrossRef] [PubMed]

26. Wu, X.; Wu, M.Y.; Jiang, M.; Zhi, Q.; Bian, X.; Xu, M.D.; Gong, F.R.; Hou, J.; Tao, M.; Shou, L.M.; et al. TNF- $\alpha$ sensitizes chemotherapy and radiotherapy against breast cancer cells. Cancer Cell Int. 2017, 17, 13. [CrossRef]

27. Donato, N.J.; Klostergaard, J. Distinct stress and cell destruction pathways are engaged by TNF and ceramide during apoptosis of MCF-7 cells. Exp. Cell Res. 2004, 294, 523-533. [CrossRef]

28. Paramanantham, A.; Kim, M.J.; Jung, E.J.; Nagappan, A.; Yun, J.W.; Kim, H.J.; Shin, S.C.; Kim, G.S. Pretreatment of Anthocyanin from the Fruit of Vitis coignetiae Pulliat Acts as a Potent Inhibitor of TNF- $\alpha$ Effect by Inhibiting NF-кB-Regulated Genes in Human Breast Cancer Cells. Molecules 2020, 25. [CrossRef]

29. Yeh, P.Y.; Yeh, K.H.; Chuang, S.E.; Song, Y.C.; Cheng, A.L. Suppression of MEK/ERK signaling pathway enhances cisplatin-induced NF-kappaB activation by protein phosphatase 4-mediated NF-kappaB p65 Thr dephosphorylation. J. Biol. Chem. 2004, 279, 26143-26148. [CrossRef]

30. Gilmore, T.D. Introduction to NF-kappaB: Players, pathways, perspectives. Oncogene 2006, 25, 6680-6684. [CrossRef]

31. Thakur, B.; Ray, P. Cisplatin triggers cancer stem cell enrichment in platinum-resistant cells through NF-кB-TNF $\alpha$-PIK3CA loop. J. Exp. Clin. Cancer Res. 2017, 36, 164. [CrossRef]

32. Lu, J.N.; Lee, W.S.; Yun, J.W.; Kim, M.J.; Kim, H.J.; Kim, D.C.; Jeong, J.H.; Choi, Y.H.; Kim, G.S.; Ryu, C.H.; et al. Anthocyanins from Vitis coignetiae Pulliat Inhibit Cancer Invasion and Epithelial-Mesenchymal Transition, but These Effects Can Be Attenuated by Tumor Necrosis Factor in Human Uterine Cervical Cancer HeLa Cells. Evid.-Based Complement. Altern. Med. Ecam 2013, 2013, 503043. [CrossRef]

33. Li, Y.; Ellis, K.-L.; Ali, S.; El-Rayes, B.F.; Nedeljkovic-Kurepa, A.; Kucuk, O.; Philip, P.A.; Sarkar, F.H. Apoptosis-Inducing Effect of Chemotherapeutic Agents Is Potentiated by Soy Isoflavone Genistein, a Natural Inhibitor of NF-kB in BxPC-3 Pancreatic Cancer Cell Line. Pancreas 2004, 28, e90-e95. [CrossRef] [PubMed]

34. Dan, H.C.; Cooper, M.J.; Cogswell, P.C.; Duncan, J.A.; Ting, J.P.; Baldwin, A.S. Akt-dependent regulation of NF-\{kappa\}B is controlled by mTOR and Raptor in association with IKK. Genes Dev. 2008, 22, 1490-1500. [CrossRef] [PubMed]

35. Lu, J.N.; Lee, W.S.; Nagappan, A.; Chang, S.H.; Choi, Y.H.; Kim, H.J.; Kim, G.S.; Ryu, C.H.; Shin, S.C.; Jung, J.M.; et al. Anthocyanins From the Fruit of Vitis coignetiae Pulliat Potentiate the Cisplatin Activity by Inhibiting PI3K/Akt Signaling Pathways in Human Gastric Cancer Cells. J. Cancer Prev. 2015, 20, 50-56. [CrossRef] 
36. Han, S.Y.; Choung, S.Y.; Paik, I.S.; Kang, H.J.; Choi, Y.H.; Kim, S.J.; Lee, M.O. Activation of NF-kappaB determines the sensitivity of human colon cancer cells to TNFalpha-induced apoptosis. Biol. Pharm. Bull. 2000, 23, 420-426. [CrossRef] [PubMed]

37. Lu, J.N.; Lee, W.S.; Kim, M.J.; Yun, J.W.; Jung, J.H.; Yi, S.M.; Jeong, J.H.; Kim, H.J.; Choi, Y.H.; Kim, G.S.; et al. The inhibitory effect of anthocyanins on Akt on invasion and epithelial-mesenchymal transition is not associated with the anti-EGFR effect of the anthocyanins. Int. J. Oncol. 2014, 44, 1756-1766. [CrossRef]

38. Yahfoufi, N.; Alsadi, N.; Jambi, M.; Matar, C. The Immunomodulatory and Anti-Inflammatory Role of Polyphenols. Nutrients 2018, 10. [CrossRef]

39. Leiherer, A.; Mündlein, A.; Drexel, H. Phytochemicals and their impact on adipose tissue inflammation and diabetes. Vasc. Pharmacol. 2013, 58, 3-20. [CrossRef]

40. Siddiqui, A.M.; Cui, X.; Wu, R.; Dong, W.; Zhou, M.; Hu, M.; Simms, H.H.; Wang, P. The anti-inflammatory effect of curcumin in an experimental model of sepsis is mediated by up-regulation of peroxisome proliferator-activated receptor-gamma. Crit. Care Med. 2006, 34, 1874-1882. [CrossRef]

41. Eigler, A.; Sinha, B.; Hartmann, G.; Endres, S. Taming TNF: Strategies to restrain this proinflammatory cytokine. Immunol. Today 1997, 18, 487-492. [CrossRef]

42. Chen, X.; Shu, Y.; Li, W.; Yin, Y. TNF-alpha-induced metastasis gene changes in MCF-7 cells. J. Nanjing Med. Univ. 2008, 22, 366-371. [CrossRef]

43. Huang, M.; Wei, H.; Ling, R.; Lv, Y. Opposite effects of TNF0 \pm on proliferation via ceramide in MDA-MB-231 and MCF-7 breast cancer cell lines. Int. J. Clin. Exp. Med. 2018, 11, 9239-9247.

44. Beg, A.A.; Baltimore, D. An essential role for NF-kappaB in preventing TNF-alpha-induced cell death. Science 1996, 274, 782-784. [CrossRef]

45. Van Antwerp, D.J.; Martin, S.J.; Kafri, T.; Green, D.R.; Verma, I.M. Suppression of TNF-alpha-induced apoptosis by NF-kappaB. Science 1996, 274, 787-789. [CrossRef]

46. Wang, C.Y.; Mayo, M.W.; Baldwin, A.S., Jr. TNF- and cancer therapy-induced apoptosis: Potentiation by inhibition of NF-kappaB. Science 1996, 274, 784-787. [CrossRef]

47. Correia, M.; Cravo, M.; Marques-Vidal, P.; Grimble, R.; Dias-Pereira, A.; Faias, S.; Nobre-Leitao, C. Serum concentrations of TNF-alpha as a surrogate marker for malnutrition and worse quality of life in patients with gastric cancer. Clin. Nutr. 2007, 26, 728-735. [CrossRef]

48. Tas, F.; Duranyildiz, D.; Argon, A.; Oguz, H.; Camlica, H.; Yasasever, V.; Topuz, E. Serum levels of leptin and proinflammatory cytokines in advanced-stage non-small cell lung cancer. Med. Oncol. 2005, 22, 353-358. [CrossRef]

49. Lee, Y.K.; Lee, W.S.; Kim, G.S.; Park, O.J. Anthocyanins are novel AMPKalpha1 stimulators that suppress tumor growth by inhibiting mTOR phosphorylation. Oncol. Rep. 2010, 24, 1471-1477. [CrossRef]

50. Boivin, D.; Blanchette, M.; Barrette, S.; Moghrabi, A.; Beliveau, R. Inhibition of cancer cell proliferation and suppression of TNF-induced activation of NFkappaB by edible berry juice. Anticancer Res. 2007, 27, 937-948.

51. Yeh, C.T.; Yen, G.C. Induction of apoptosis by the Anthocyanidins through regulation of Bcl-2 gene and activation of c-Jun N-terminal kinase cascade in hepatoma cells. J. Agric. Food Chem. 2005, 53, 1740-1749. [CrossRef] [PubMed]

52. Kim, H.J.; Tsoy, I.; Park, J.M.; Chung, J.I.; Shin, S.C.; Chang, K.C. Anthocyanins from soybean seed coat inhibit the expression of TNF- $\alpha$-induced genes associated with ischemia/reperfusion in endothelial cell by NF- $\mathrm{BB}$-dependent pathway and reduce rat myocardial damages incurred by ischemia and reperfusion in vivo. FEBS Lett. 2006, 580, 1391-1397. [CrossRef] [PubMed]

Sample Availability: Samples of the compounds are not available from the authors. 